\title{
Evaluation of Antioxidant Activities of Water Extract from Microwave Torrefied Oak Wood $^{1}$
}

\author{
Jeong Bin $\mathrm{Nam}^{2} \cdot$ Geun Hye $\mathrm{Oh}^{3} \cdot$ Seung Min $\mathrm{Yang}^{3} \cdot$ Seok-Eon Lee ${ }^{4} \cdot$ Seog-Goo Kang ${ }^{3, \dagger}$
}

\begin{abstract}
The aim of this study was to assess the in vitro potential of water extract from torrefied oak wood as a natural antioxidant. The antioxidant potential of the extracts was assessed by employing different in vitro assays, including reducing power, DPPH (2,2-diphenyl-1-picrylhydrazyl), ABTS [2,2'-azino-bis(3-ethylbenzothiazoline-6-sulphonic acid)], and FRAP (ferric reducing antioxidant potential) assays. The DPPH activity of the extract was increased in a dosedependent manner. Measurement of total flavonoid content of water extract from torrefied oak wood was achieved using an aluminum chloride colorimetric assay; the extract contained $192.12 \mathrm{mg} / \mathrm{g}$ flavonoid, which was significantly high when compared with standard quercetin. The results obtained in this study indicate that water extract from torrefied oak wood has significant potential for use as a natural antioxidant agent.
\end{abstract}

Keywords: torrefaction, torrefied wood powder, wood roasting, antioxidant, free radical

\section{INTRODUCTION}

Antioxidants help organisms deal with oxidative stress caused by free radical damage. Free radicals are a chemical species containing one or more unpaired electrons due to which they are highly unstable and cause damage to other molecules by extracting electrons from them to attain stability (Ali et al., 2008). Recent investigations have shown that antioxidants of plant origin having free-radical scavenging properties could have potential as therapeutic agents in the aging process and in treating free radical-mediated diseases such as neurodegeneration (Singh and Singh, 1986; Singh and
Singh, 1980). Synthetic antioxidants, including butylated hydroxyanisole (BHA) and butylated hydroxytolune (BHT), have restricted use in foods because these synthetic antioxidants are suspected to be carcinogenic (Madhavi and Salunkhe, 1995). Many synthetic antioxidant compounds have shown toxic and/or mutagenic effects, which has stimulated research into natural and effective antioxidant alternatives (Nagulendran et al., 2007). Certain plant extracts and products, including flavonoids and other polyphenolic constituents, have been reported as effective radical scavengers and inhibitors of lipid peroxidation (Ohira et al., 1998; Sonwa and König, 2001).

${ }^{1}$ Date Received January 31, 2018, Date Accepted March 12, 2018

2 Institute of Agricultural Science, Chungnam National University, Daejeon 34134, Republic of Korea

${ }^{3}$ Department of Biobased Materials, College of Agriculture and Life Science, Chungnam National University, Daejeon 34134, Republic of Korea

${ }^{4}$ FITI Testing \& Research Institute, Ochang-eup, Cheongwon-gu, Cheongju 28115, Republic of Korea

$\dagger$ Corresponding author: Seog-Goo Kang(e-mail: lachesis@cnu.ac.kr, ORCID: 0000-0002-2440-7070) 
However, many antioxidative phenolic compounds in plants are predominantly present in a covalently bound form with an insoluble polymer (Niwa and Miyachi, 1986). Therefore, it is necessary to find an effective processing method to release these compounds. Several methods, including heat treatment (steam explosion and torrefaction), far-infrared (FIR) radiation, and enzymatic treatment, have been studied in order to liberate and activate low-molecular-weight antioxidants from various plants (Gong et al., 2012; Ahajji et al., 2009; Lee et al., 2003; Duh et al., 2001; Jung et al., 2016).

Heat treatment of wood at moderate temperatures $\left(200 \sim 250^{\circ} \mathrm{C}\right)$ under an inert atmosphere (to avoid oxidative degradation) leads to formation of torrefied or heat-treated wood (Ahajji et al., 2009). A recent study of the impact of torrefaction on lignocellulosic structures confirmed that mild torrefaction is a promising operation in the pretreatment of biomass for biofuel production (Chen and Kuo, 2010).

Additionally, biomass torrefaction: 1) improves the crushability of fibrous materials; 2) reduces the energy demand for material crushing prior to hydrolysis; 3 ) decomposes the biomass structure; and 4) improves the accessibility of enzymes for hydrolysis (Chiaramonti et al., 2011). This process lowers the water content of the biomass, and increases the energy density and crushability of the material (Repellin et al., 2010; Arias et al., 2008; Sheikh et al., 2013).

Antioxidative phenolic compounds can be present in raw materials or produced during the heat-treatment process. In this temperature range $\left(200 \sim 250^{\circ} \mathrm{C}\right)$, hemicelluloses are the most affected macromolecules in wood: at $180^{\circ} \mathrm{C}$, depolymerization of these components is accompanied by the release of low-molecular-weight compounds, including acetic acid, furfural, methanol, and $\mathrm{CO}_{2}$ (Avat, 1989). Previous studies have shown that the heat treatment of wood increases antioxidant activity; following torrefaction, the concentration of certain phenolic compounds, including syringyl and guaiacyl, increased (Ahajji et al., 2009; Khazraie Shoulaifar et al., 2014).

The purpose of the present study was to determine the antioxidant activity of torrefied oak wood extracts using their free radical scavenging property. Additionally, we investigated the feasibility of using these extracts with antioxidant activities as a dietary supplement for poultry.

\section{MATERIALS and METHODS}

\subsection{Extraction Procedure of Torrefied Oak Wood}

Torrefaction of the oak wood (Qercus variabilis Blume) chips was achieved using a laboratory scale reactor. A prescribed amount of oak wood chips was weighed and placed in the center of the reactor. An external dryer was used to dry the chips to $<15 \%$ moisture prior to torrefaction. The oak wood chips were torrefied at $240^{\circ} \mathrm{C}$ temperatures for $24 \mathrm{~h}$. After torrefaction, the material was ground and sieved to a maximum particle size of 60 mesh. The torrefied material was stored in a desiccator at room temperature until chemical analysis. The phenolic compounds were isolated from the extracts following previously described methods, with certain modifications (Gong et al., 2012). Extractions of torrefied oak wood were performed in bottles using water. In general, an amount of 1.5, 3, $6,12,25 \mathrm{~g}$ of torrefied oak wood was placed in a bottle with $100 \mathrm{~mL}$ of water. Upon completion of extraction, the extract was filtered through a filter paper.

\subsection{Determination of Total Polyphenol Content}

The total polyphenol content was determined by the Folin-Ciocalteu method according to the reported procedure (Li et al., 2008). $1 \mathrm{~mL}$ extracts with proper 
Jeong Bin Nam $\cdot$ Geun Hye Oh $\cdot$ Seung Min Yang $\cdot$ Seok-Eon Lee $\cdot$ Seog-Goo Kang

dilution were mixed with $1 \mathrm{~mL}$ of Folin-Ciocalteu reagent. Then, an amount of $1 \mathrm{~mL}$ of saturated $\mathrm{Na}_{2} \mathrm{CO}_{3}$ solution was added, and the mixture was allowed to stand for $1 \mathrm{~h}$. The absorbance of the reaction mixture at $765 \mathrm{~nm}$ was measured by using a spectrophotometer (Humas HS-3300, Daejeon, Korea). A calibration curve of gallic acid was prepared, and the total polyphenol content was standardized against gallic acid and expressed as mg GAE equivalent per gram of dry torrefied wood.

\subsection{Determination of Total Flavonoid Content}

The total flavonoid content was determined by aluminum chloride colorimetric assay (Abeysinghe et al., 2007). Briefly, $1 \mathrm{~mL}$ of extract was mixed with 10 $\mathrm{mL}$ of diethylene glycol, and $1 \mathrm{~mL}$ of $1 \mathrm{~N} \mathrm{NaOH}$ and left at room temperature for $1 \mathrm{~h}$. The absorbance of the reaction mixture at $420 \mathrm{~nm}$ was measured by using a spectrophotometer (Humas HS-3300, Daejeon, Korea). The total flavonoid content was calculated as quercetin from a calibration curve. A calibration curve of quercetin was prepared, and the total flavonoid content was standardized against quercetin and expressed as mg QE equivalent per gram of dry torrefied wood.

\subsection{Free Radical Scavenging by the Use of the DPPH Radical}

The DPPH radical scavenging activity was calculated based on the change of absorbance due to the decrease in 2,2-diphenyl-1-picrylhydrazyl (DPPH) in relation to the control value (Brand-Williams et al., 1995). Considering the color of the extract, an ethanol solution $(1 \mathrm{~mL})$ was used as a color blank instead of $0.5 \mathrm{mM}$ DPPH in ethanol $(1 \mathrm{~mL})$. As the control, water or ethanol $(1 \mathrm{~mL})$ was added instead of the extract. In the following, a $0.1 \mathrm{mM}$ ethanolic DPPH solution was prepared. The initial absorbance of the
DPPH in ethanol was measured at $517 \mathrm{~nm}$, and it did not change throughout the period of the assay. $1 \mathrm{~mL}$ extract was mixed with $4 \mathrm{~mL}$ of ethanolic DPPH solution and incubated for $30 \mathrm{~min}$ at room temperature in the dark. Then, the absorbance at $517 \mathrm{~nm}$ was measured. The DPPH radical scavenging activity (\%) was calculated by the following equation:

$$
\mathrm{DPPH}(\%)=(1-\mathrm{A} \text { sample } / \mathrm{A} \text { control }) \times 100
$$

where A sample is the absorbance in the presence of the sample, and A control is the absorbance in the absence of the sample.

\subsection{Reducing Power Assay}

The reducing power was determined according to the method of Oyaizu (1986). Various concentrations of extract $(0.5 \mathrm{~mL})$ was mixed with $2.5 \mathrm{ml}$ of $0.2 \mathrm{~mol} / \mathrm{L}$ sodium phosphate buffer $(\mathrm{pH} 6.6)$ and $2.5 \mathrm{~mL}$ of $1 \%$ potassium ferricyanide. The mixture was incubated at $50{ }^{\circ} \mathrm{C}$ for $20 \mathrm{~min}$. After $2.5 \mathrm{~mL}$ of $10 \%$ trichloroacetic acid (TCA) (w/v) were added, the mixture was centrifuged at $650 \mathrm{rpm}$ for $10 \mathrm{~min}$. The upper layer $(2.5 \mathrm{~mL})$ was mixed with $2.5 \mathrm{~mL}$ deionised water and $0.5 \mathrm{~mL}$ of $0.1 \%$ of ferric chloride, and the absorbance was measured at $700 \mathrm{~nm}$ : higher absorbance indicates higher reducing power. The assays were carried out in triplicate and the results are expressed as mean values \pm standard deviations.

\subsection{Free Radical Scavenging by the Use of the ABTS Radical}

For ABTS [2,2'-azino-bis(3-ethylbenzothiazoline-6sulphonic acid)] assay, the procedure followed the method of Re et al. (1999) with some modifications. The stock solutions included $7.4 \mathrm{mM}$ ABTS+ solution and $2.6 \mathrm{mM}$ potassium persulfate solution. The working solution was then prepared by mixing the two stock 
solutions in equal quantities and allowing them to react for $12 \mathrm{~h}$ at room temperature in the dark. The solution was then diluted by mixing $1 \mathrm{~mL}$ ABTS+ solution with $60 \mathrm{~mL}$ methanol to obtain an absorbance of $1.1 \pm 0.02$ units at $734 \mathrm{~nm}$ using the spectrophotometer. Fresh ABTS+ solution was prepared for each assay. Extracts $(150 \mathrm{uL})$ were allowed to react with $2850 \mathrm{uL}$ of the ABTS+ solution for $2 \mathrm{~h}$ in a dark condition. Then the absorbance was taken at $734 \mathrm{~nm}$ using the spectrophotometer.

\subsection{Ferric Reducing Antioxidant Potential (FRAP) Assay}

The ferric reducing power of plant extracts was determined using a modified version of the FRAP (Ferric reducing antioxidant potential) assay (Benzie and Strain, 1996). This method is based on the reduction, at low $\mathrm{pH}$, of a colorless ferric complex ( $\mathrm{Fe}^{3+}$-tripyridyltriazine) to a blue-colored ferrous complex $\left(\mathrm{Fe}^{2+}\right.$ - tripyridyltriazine) by the action of electrondonating antioxidants. The reduction is monitored by measuring the change of absorbance at $593 \mathrm{~nm}$. The working FRAP reagent was prepared daily by mixing

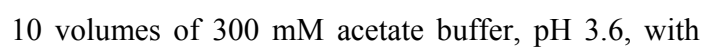
1 volume of $10 \mathrm{mM}$ TPTZ (2,4,6-tri (2-pyridyl)-striazine) in $40 \mathrm{mM}$ hydrochloric acid and with 1 volume of $20 \mathrm{mM}$ ferric chloride. All solutions were used on the day of preparation. One hundred microliters of sample solutions and $300 \mathrm{uL}$ of deionized water were added to $3 \mathrm{~mL}$ of freshly prepared FRAP reagent. The reaction mixture was incubated for $30 \mathrm{~min}$ at $37^{\circ} \mathrm{C}$ in a water bath. Then, the absorbance of the samples was measured at $593 \mathrm{~nm}$. A sample blank reading using acetate buffer was also taken. The difference between sample absorbance and blank absorbance was calculated and used to calculate the FRAP value. In this assay, the reducing capacity of the plant extracts tested was calculated with reference to the reaction signal given by a $\mathrm{Fe}^{2+}$ solution. FRAP values were expressed as $\mathrm{mmol} \mathrm{Fe}^{2+} / \mathrm{g}$ of sample.

\subsection{Statistical Analysis}

All experiments were repeated three times, and results are expressed as the mean \pm standard deviation. Statistical analysis was performed using SPSS software, and statistical significance of the extract antioxidative effects was determined at 95\% using the Duncan's multiple range test.

\section{RESULTS and DISCUSSION}

\subsection{Total Polyphenol Content}

Plant phenolic compounds have various physiological functions, including antimutagenic, cholesterol-lowering, anticancer, and antioxidant effects. Phenolic hydroxyl groups in the molecule bind to other macromolecules, including enzyme, It is known that it is recognized as a subject showing such a physiological activity function (Jung, 2004). Regarding the antioxidative actions, various oxygen free radical reactions in vivo are associated with aging and/or disease in living tissues. The hydroxyl group of the phenolic compound is a

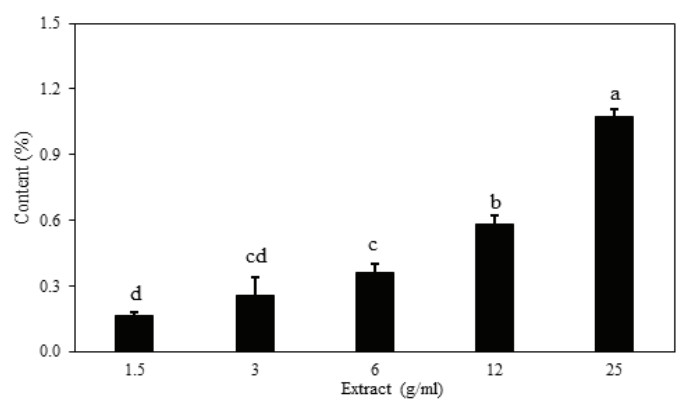

Fig. 1. Content of total polyphenol content in water extract from torrefied oak wood. All values are expressed as mean $\pm \mathrm{SD}(\mathrm{n}=3)$. Means with different letters (a-d) above the bars are significantly different by Duncan's multiple range test $(\mathrm{p}<0.05)$. 
free radical receptor of fat, thus inhibiting oxidation (Ahn et al., 1996). Phenolic compounds were therefore extracted from the samples under the aforementioned conditions and their contents were measured. The total polyphenol content of the extract was measured using a gallic acid standard curve. The results are shown in Fig. 1. The total polyphenol contents of the extracts were $0.16,0.26,0.36,0.58$ and $1.07 \mathrm{mg} / \mathrm{mL}$, respectively which were lower than those of the untreated oak wood extracts, as well as those of other treatments (Nam et al., 2014).

\subsection{Total Flavonoid Content}

Flavonoids are the most common sub-group of the polyphenols, have c6-c3-c6 as a basic skeleton, and are yellow or light yellow in color. Flavonoids are widely distributed in nature and are known to be abundant in vegetables, grains, and fruits including the stems and roots (Hertog et al., 1993). Flavonoids have high antioxidant abilities, effectively eliminating all reactive oxygen species, as well as antiviral, anti-inflammatory, and anticancer effects, similar to other polyphenols (Tsao, 2010). The total flavonoid content of the extracts was measured using a quercetin standard curve, and

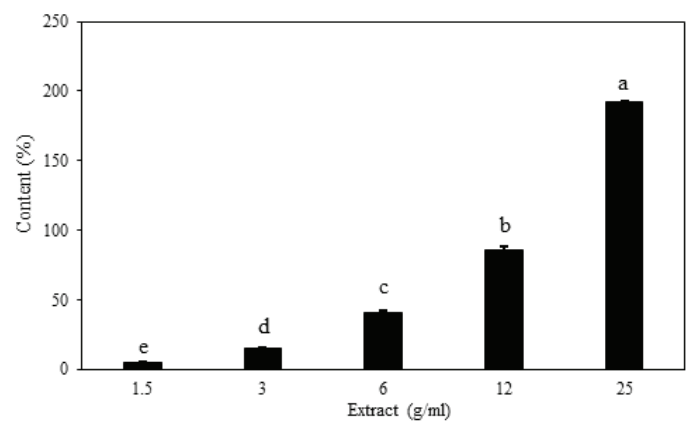

Fig. 2. Content of total flavonoid content in water extract from torrefied oak wood. All values are expressed as mean $\pm \mathrm{SD}(\mathrm{n}=3)$. Means with different letters (a-e) above the bars are significantly different by Duncan's multiple range test $(\mathrm{p}<0.05)$. the results are shown in Fig. 2. The total polyphenol contents of the extracts were 4.64, 15.09, 40.32, 85.36 and $192.12 \mathrm{mg} / \mathrm{mL}$, respectively. The extract polyphenol contents were lower than those of the oak extracts, but the flavonoid content was higher.

\subsection{Inhibition of DPPH Radical}

\section{1,1-Diphenyl-2-picrylhydrazyl (DPPH) is relatively} stable compared with the highly reactive superoxide and hydroxyl species that are primarily responsible for oxidative damage in biological systems. It is widely used to test the ability of compounds to act as free radical scavengers or hydrogen donors. The DPPH molecule is considered a model for a lipophilic radical. A certain chain in lipophilic radicals is initiated by lipid auto-oxidation (Cotelle et al., 1996; von Gadow et al., 1997; Soare et al., 1997). DPPH is a stable free radical at room temperature, and accepts an electron or hydrogen to become a stable diamagnetic molecule (Chen and Ho, 1995). The reduction capability of DPPH was determined by the decrease in its absorbance at $517 \mathrm{~nm}$, which is induced by antioxidants. A positive DPPH test suggests that the samples were free radical scavengers. Varied extract

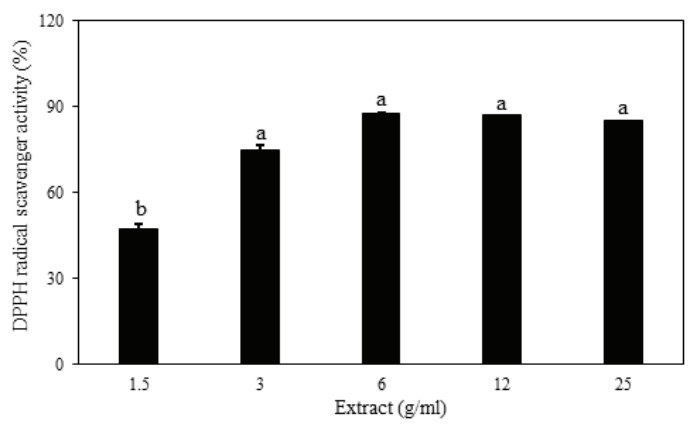

Fig. 3. DPPH radical scavenger activity in water extract from torrefied oak wood. All values are expressed as mean $\pm \mathrm{SD}(\mathrm{n}=3)$. Means with different letters (a-b) above the bars are significantly different by Duncan's multiple range test $(\mathrm{p}<0.05)$. 
concentrations $(1.5,3,6,12$ and $25 \mathrm{~g} / \mathrm{mL})$ showed that antioxidant activities were dose-dependent (47.20, $74.78,87.41,87.19$ and $85.34 \%$, respectively) in the DPPH radical scavenging assay. The antioxidant activities of each extract and extract concentration was compared using the differences in the reference densities. These results suggest that the extracts are valuable natural resources with excellent antioxidant ability.

\subsection{Reducing Power}

Ferrous ions $\left(\mathrm{Fe}^{2+}\right)$ was measured spectrophotometrically at $700 \mathrm{~nm}$, with higher absorbance values indicative of greater reducing capacity of ferric $\left(\mathrm{Fe}^{3+}\right)$ to ferrous $\left(\mathrm{Fe}^{2+}\right)$ ions (Lue et al., 2010). It is considered that the higher the absorbance value, the better the reducing power. The reducing activity of extracts of torrefied oak wood. Moieties with reducing power show that they are electron donors, and they can reduce the oxidized intermediates so they can act as antioxidants. As with the antioxidant activity, the reducing power of the water extract from torrefied oak wood was also concentration-dependent. Hence, the reducing power of the extract is increased as the concentration is increased.

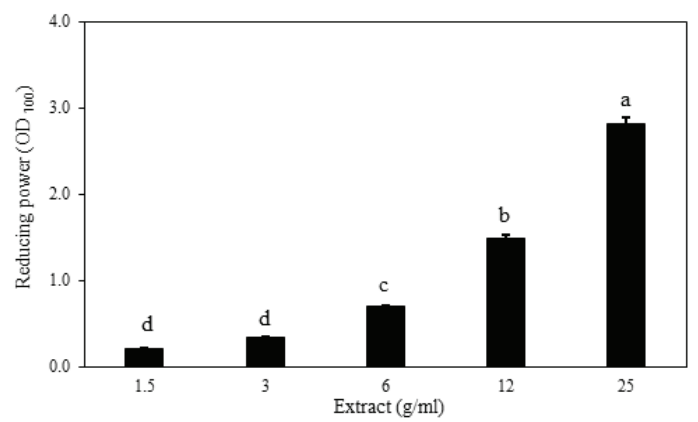

Fig. 4. Reducing power activity in water extract from torrefied oak wood. All values are expressed as mean \pm SD ( $n=3)$. Means with different letters (a-d) above the bars are significantly different by Duncan's multiple range test $(\mathrm{p}<0.05)$.
The reducing power of the $25 \mathrm{~g} / \mathrm{mL}$ extract was significantly higher than that of the $1.5,3$, and $6 \mathrm{~g} / \mathrm{mL}$ extracts, but there was no significant difference between the 12.5 and $25 \mathrm{~g} / \mathrm{mL}$ extracts $(\mathrm{p}>0.05)$.

\subsection{ABTS}

DPPH and ABTS assays are widely used to determine the radical scavenging ability of various samples (Marowicz et al., 2004; Jang et al., 2007; Bursal and Gülçin, 2011). The DPPH assay is useful for determination of the free radical scavenging ability of extracts; the ABTS radical decay assay can be used to measure the kinetics of the free radical scavenging power of extracts. ABTS radicals are more reactive than DPPH radicals, and, unlike the reactions with DPPH, the reactions with ABTS radicals generally occur in less than a millisecond (Naik et al., 2003). ABTS radical cation decolorization can measure both hydrogen-donating antioxidants and chain-breaking antioxidants, and it can be applied to both the aqueous and the organic phases. ABTS+ free radicals generated by a reaction with potassium persulfate can be removed by antioxidants in the extract. It is radically discordant to discoloration of a specific index of cyan. (Leong and Shui, 2002;

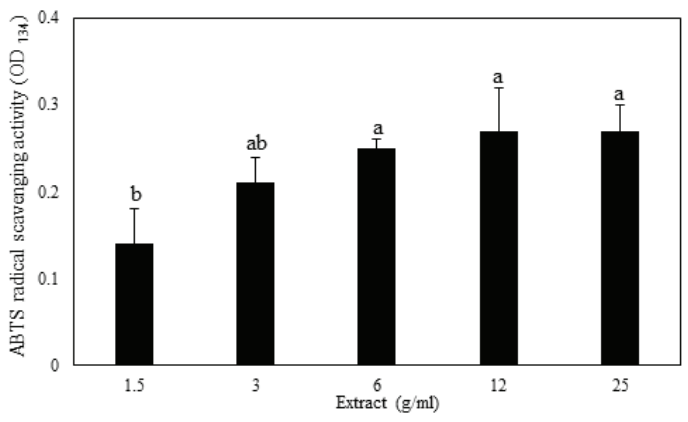

Fig. 5. ABTS value in water extract from torrefied oak wood. All values are expressed as mean \pm SD $(n=3)$. Means with different letters $(a-b)$ above the bars are significantly different by Duncan's multiple range test $(\mathrm{p}<0.05)$. 
Aktumsek et al., 2013). ABTS is generally used for testing the preliminary radical scavenging activity of antioxidant compounds and/or plant extracts. The ABTS scavenging capacity of plant extracts was expressed as an inhibition capacity, and the results are shown in Fig. 5. ABTS radical scavenging activity tended to increase in a dose-dependent manner, similar to that of the free radical scavenging activity. The assay provided measurements of $0.25 \pm 0.01$ at a $6 \mathrm{~g} / \mathrm{mL}$ concentration, and $0.27 \pm 0.03$ for the $25 \mathrm{~g} / \mathrm{mL}$ extract. In addition, the polyphenol and ABTS contents were low, but the phenolic compound profile associated with the antioxidant activity may still be contained within the extract.

\subsection{FRAP}

The FRAP assay is based on the ability of an antioxidant to reduce $\mathrm{Fe}^{3+}$ to $\mathrm{Fe}^{2+}$ in the presence of TPTZ, forming an intense blue $\mathrm{Fe}^{2+}$ - TPTZ complex with an absorption maximum at $593 \mathrm{~nm}$. This reaction is pH-dependent. The absorbance value decrease is proportional to the antioxidant content of the extract (Liu et al., 2009). Studies have indicated that the antioxidant effect is associated with the development of reductones

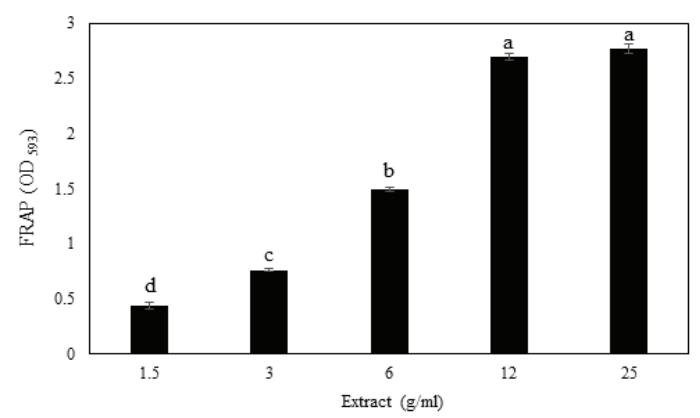

Fig. 6. FRAP value in water extract from torrefied oak wood. All values are expressed as mean \pm SD $(n=3)$. Means with different letters (a-d) above the bars are significantly different by Duncan's multiple range test $(\mathrm{p}<0.05)$.
(Yen and Duh, 1993). Briefly, reductones are reported to be terminators of free radical chain reactions; thus, the antioxidant activity of an aqueous extract may be associated with its reductive activity (Gordon, 1990; Dorman et al., 2003). The antioxidant activity of FRAP was increased accordingly with increases in the extract concentration. As shown in the figure, FRAP activity was determined to be $0.44 \pm 0.03,0.76 \pm 0.01,1.49$ $\pm 0.02,2.70 \pm 0.03$, and $2.77 \pm 0.04$ at extract concentrations of $1.5,3,6,12.5$, and $25 \mathrm{~g} / \mathrm{ml}$, respectively. In the case of FRAP activity, it is presumed that the specific color of the sample affected the experimental data.

\subsection{Correlation between Assays}

To correlate the results obtained with the different methods, a regression analysis was performed (correlation coefficient (R), Table 1). Significant correlations were found between the various methods used to determine the antioxidant potential, especially between DPPH and ABTS assays $(\mathrm{R}=0.9505)$, and ABTS and FRAP assays $(\mathrm{R}=0.7859)$. The lowest correlations were found between the FRAP and DPPH assays $(\mathrm{R}=0.5812)$. The lowest correlations were found between the FRAP and DPPH assays $(\mathrm{R}=0.5812)$.

The correlation between total polyphenol contents and DPPH of extracts had a correlation coefficient of $\mathrm{R}=0.3538$.

A strong correlation was found between the ferric reducing potential, determined by the FRAP assay, and

Table 1. Correlation coefficient (R) between assays in water extract from torrefied oak wood

\begin{tabular}{ccccc}
\hline & TP & TF & DPPH & ABTS \\
\hline \hline TF & $\mathbf{0 . 9 9 7 3}$ & & & \\
DPPH & 0.3538 & 0.3139 & & \\
ABTS & 0.5408 & 0.5001 & 0.9505 & \\
FRAP & 0.7718 & 0.7542 & 0.5812 & 0.7859 \\
\hline
\end{tabular}


total polyphenolic content $(\mathrm{R}=0.7718)$. It can be concluded that antioxidant activity of plant extracts is not limited to phenolics. These results indicate a relationship between phenolic compound concentration in plant extracts and their free radical scavenging and ferric reducing capacities. Therefore, the presence of phenolic compounds in plant extracts contributes significantly to their antioxidant potential. This result is in agreement with previous reports that ferric reducing potential can be related to phenolic content (Katalinic et al., 2006; Wong et al., 2006; Dudonné et al., 2009).

\section{CONCLUSION}

The antioxidant activity of the extracts extracted by the cold water extraction method was evaluated to evaluate the applicability of the water extract from torrefied oak wood as an antioxidant. The DPPH radical scavenging activity was evaluated as a high radical scavenging activity of more than $80 \%$ at $12 \mathrm{~g} / \mathrm{mL}$. As a result of the evaluation of FRAP activity, DPPH radical scavenging activity showed excellent activity. Reducing power and ABTS activity of the water extract from torrefied oak wood were dose dependent. ABTS activity was slightly lower than that of radical scavenging activity and FRAP activity. Therefore, the antioxidative effect of the water extract from torrefied oak wood is thought to be due to its high radical scavenging activity and high reducing power. The antioxidant activity of antioxidant activity of antioxidant activity was correlated with that of phenolic compounds. It is considered that the water extract from torrefied oak wood contains antioxidant activity by containing phenolic compounds. Therefore, the use of a small amount of the extract for the dietary supplementation of poultry is predicted to convey the benefits of the reported multiple antioxidant activities (Puthpongsiriporn et al., 2001; Mielnik et al., 2006; Luber et al., 2003), and hence have a positive effect on the productivity of breeding poultry.

\section{ACKNOWLEDGMENT}

This study was carried out with the support of 'R\&D Program for Forest Science Technology (Project No. 2014068D10-1719-AA03)' provided by Korea

Forest Service (Korea Forestry Promotion Institute).

\section{REFERENCES}

Abeysinghe, D.C., Li, X., Sun, C., Zhang, W., Zhou, C., Chen, K. 2007. Bioactive compounds and antioxidant capacities in different edible tissues of citrus fruit of four species. Food chemistry 104(4): 1338-1344.

Ahajji, A., Diouf, P.N., Aloui, F., Elbakali, I., Perrin, D., Merlin, A., George, B. 2009. Influence of heat treatment on antioxidant properties and colour stability of beech and spruce wood and their extractives. Wood Science and Technology 43(1-2): 69.

Ahn, Y.J., Lee, S.H., Kang, S.J., Hwang, B.Y., Park, W.Y., Ahn, B.T., Lee, K.S. 1996. The phenolic components of Sapium japonicum. Yakhak Hoeji pp. 40.

Aktumsek, A., Zengin, G., Guler, G.O., Cakmak, Y.S., Duran, A. 2013. Antioxidant potentials and anticholinesterase activities of methanolic and aqueous extracts of three end,emic Centaurea L. species. Food and Chemical Toxicology 55: 290-296.

Ali, S.S., Kasoju, N., Luthra, A., Singh, A., Sharanabasava, H., Sahu, A., Bora, U. 2008. Indian medicinal herbs as sources of antioxidants, Food Research International 41(1): 1-15.

Arias, B., Pevida, C., Fermoso, J., Plaza, M.G., Rubiera, F., Pis, J.J. 2008. Influence of torrefaction on the grindability and reactivity of woody biomass. Fuel Processing Technology 89(2): 169-175.

Avat, F. 1989. Nature et rôle des extractibles dans la rétification du bois. DEA EMSE. St-Etienne. 
Benzie, I.F., Strain, J.J. 1996. The ferric reducing ability of plasma (FRAP) as a measure of "antioxidant power": the FRAP assay. Analytical biochemistry 239(1): 70-76.

Brand-Williams, W., Cuvelier, M.E., Berset, C.L.W.T. 1995. Use of a free radical method to evaluate antioxidant activity. LWT-Food science and Technology 28(1): 25-30.

Bursal, E., Gülçin, İ. 2011. Polyphenol contents and in vitro antioxidant activities of lyophilised aqueous extract of kiwifruit (Actinidia deliciosa). Food Research International 44(5): 1482-1489.

Chen, C.W., Ho, C.T. 1995. Antioxidant properties of polyphenols extracted from green and black teas. Journal of food lipids 2(1): 35-46.

Chen, W.H., Kuo, P.C. 2010. A study on torrefaction of various biomass materials and its impact on lignocellulosic structure simulated by a thermogravimetry. Energy 35(6): 2580-2586.

Chiaramonti, D., Rizzo, A.M., Prussi, M., Tedeschi, S., Zimbardi, F., Braccio, G., Pardelli, P.T. 2011. 2nd generation lignocellulosic bioethanol: is torrefaction a possible approach to biomass pretreatment? Biomass Conversion and Biorefinery 1(1): 9-15.

Cotelle, N., Bernier, J.L., Catteau, J.P., Pommery, J., Wallet, J.C., Gaydou, E.M. 1996. Antioxidant properties of hydroxy-flavones. Free Radical Biology and Medicine 20(1): 35-43.

Dorman, H.D., Koşar, M., Kahlos, K., Holm, Y., Hiltunen, R. 2003. Antioxidant properties and composition of aqueous extracts from Mentha species, hybrids, varieties, and cultivars. Journal of agricultural and food chemistry 51(16): 4563-4569.

Duh, P.D., Yen, G.C., Yen, W.J., Chang, L.W. 2001. Antioxidant effects of water extracts from barley (Hordeum vulgare L.) prepared under different roasting temperatures. Journal of agricultural and food chemistry 49(3): 1455-1463.
Gong, L., Huang, L., Zhang, Y. 2012. Effect of steam explosion treatment on barley bran phenolic compounds and antioxidant capacity. Journal of agricultural and food chemistry 60(29): 7177-7184.

Gordon, M.H. 1990. The mechanism of antioxidant action in vitro. In Food antioxidants Springer Netherlands. pp. 1-18.

Hertog, M.G., Hollman, P.C., Van de Putte, B. 1993. Content of potentially anticarcinogenic flavonoids of tea infusions, wines, and fruit juices. Journal of agricultural and food chemistry 41(8): 12421246.

Jang, H.D., Chang, K.S., Huang, Y.S., Hsu, C.L., Lee, S.H., Su, M.S. 2007. Principal phenolic phytochemicals and antioxidant activities of three Chinese medicinal plants. Food chemistry 103(3): 749-756.

Jung, H.K. 2004. Investigation of the physiological activity of grapes and development of the functional processed food by use of grapes containing antioxidant ingredients. The Ministry of Agriculture and Forestry (201016-3). p. 63.

Jung, J.Y., Park, H.M., Yang, J.K. 2016. Optimization of ethanol extraction of antioxidative phenolic compounds from torrefied oak wood (Quercus serrata) using response surface methodology. Wood science and technology 50(5): 1037-1055.

Katalinic, V., Milos, M., Kulisic, T., Jukic, M. 2006. Screening of 70 medicinal plant extracts for antioxidant capacity and total phenols. Food chemistry 94(4): 550-557.

Khazraie Shoulaifar, T., DeMartini, N., Willför, S., Pranovich, A., Smeds, A.I., Virtanen, T.A.P., Hupa, M. 2014. Impact of torrefaction on the chemical structure of birch wood. Energy \& Fuels 28(6): 3863-3872.

Lee, S.C., Kim, J.H., Jeong, S.M., Kim, D.R., Ha, J.U., Nam, K.C., Ahn, D.U. 2003. Effect of far-infrared radiation on the antioxidant activity of rice hulls. 
Journal of agricultural and food chemistry 51(15): 4400-4403.

Leong, L.P., Shui, G. 2002. An investigation of antioxidant capacity of fruits in Singapore markets. Food chemistry 76(1): 69-75.

Li, H.B., Wong, C.C., Cheng, K.W., Chen, F. 2008. Antioxidant properties in vitro and total phenolic contents in methanol extracts from medicinal plants. LWT-Food Science and Technology 41(3): 385-390.

Liu, L., Sun, Y., Laura, T., Liang, X., Ye, H., Zeng, X. 2009. Determination of polyphenolic content and antioxidant activity of kudingcha made from Ilex kudingcha CJ Tseng. Food Chemistry 112(1): $35-41$.

Luber, P., Wagner, J., Hahn, H., Bartelt, E. 2003. Antimicrobial resistance in Campylobacter jejuni and Campylobacter coli strains isolated in 1991 and 2001-2002 from poultry and humans in Berlin, Germany. Antimicrobial Agents and Chemotherapy 47(12): 3825-3830.

Lue, B.M., Nielsen, N.S., Jacobsen, C., Hellgren, L., Guo, Z., Xu, X. 2010. Antioxidant properties of modified rutin esters by DPPH, reducing power, iron chelation and human low density lipoprotein assays. Food Chemistry 123(2): 221-230.

Madhavi, D.L., Salunkhe, D.K. 1995. Toxicological aspects of food antioxidants. Food science and technology: New York-marcel dekker, 267-360.

Marowicz, R., Pegg, R.B., Rahimi-Moghaddam, P., Barl, B., Weil, J.A. 2004. Free-radical scavenging capacity and antioxidant activity of selected plant species from the Canadian prairies. Food chemistry 84(4): 551-562.

Mielnik, M.B., Olsen, E., Vogt, G., Adeline, D., Skrede, G. 2006. Grape seed extract as antioxidant in cooked, cold stored turkey meat. LWT-Food science and technology 39(3): 191-198.

Nagulendran, K.R., Velavan, S., Mahesh, R., Begum, V.H. 2007. In vitro antioxidant activity and total polyphenolic content of Cyperus rotundus rhizomes. Journal of Chemistry 4(3): 440-449.

Naik, G.H., Priyadarsini, K.I., Satav, J.G., Banavalikar, M.M., Sohoni, D.P., Biyani, M.K., Mohan, H. 2003. Comparative antioxidant activity of individual herbal components used in Ayurvedic medicine. Phytochemistry 63(1): 97-104.

Nam, J.B., Park, H.B., Jung, J.Y., Yang, J.K. 2014. Protective Effect of Oak Extracts on Oxidative Stress Induced by Hydrogen Peroxide. Journal of the Korean Wood Science and Technology 42(5): 523-532.

Niwa, Y., Miyachi, Y. 1986 Antioxidant action of natural health products and Chinese herbs. Inflammation 10(1): 79-91.

Ohira, S., Hasegawa, T., Hayashi, K.I., Hoshino, T., Takaoka, D., Nozaki, H. 1998. Sesquiterpenoids from Cyperus rotundus. Phytochemistry 47(8): 1577-1581.

Oyaizu, M. 1986. Studies on products of browning reaction. The Japanese Journal of Nutrition and Dietetics 44(6): 307-315.

Puthpongsiriporn, U., Scheideler, S.E., Sell, J.L., Beck, M.M. 2001. Effects of vitamin E and C supplementation on performance, in vitro lymphocyte proliferation, and antioxidant status of laying hens during heat stress. Poultry science 80(8): 1190-1200.

Re, R., Pellegrini, N., Proteggente, A., Pannala, A., Yang, M., Rice-Evans, C. 1999. Antioxidant activity applying an improved ABTS radical cation decolorization assay. Free radical biology and medicine 26(9): 1231-1237.

Repellin, V., Govin, A., Rolland, M., Guyonnet, R. 2010. Energy requirement for fine grinding of torrefied wood. Biomass and Bioenergy 34(7): 923-930.

Sheikh, M.M.I., Kim, C.H., Park, H.J., Kim, S.H., Kim, G.C., Lee, J.Y., Kim, J.W. 2013. Effect of torrefaction for the pretreatment of rice straw for 
ethanol production. Journal of the Science of Food and Agriculture 93(13): 3198-3204.

Singh, N.B., Singh, P.N. 1986. A new flavonol glycoside from the mature tubers of Cyperus rotundus L. Journal of the Indian Chemical Society 63(4): 450-450.

Singh, P.N., Singh, S.B. 1980. A new saponin from mature tubers of Cyperus rotundus. Phytochemistry 19(9): 2056.

Soare, J.R., Dinis, T.C., Cunha, A.P., Almeida, L. 1997. Antioxidant activities of some extracts of Thymus zygis. Free radical research 26(5): 469-478.

Sonwa, M.M., König, W.A. 2001. Chemical study of the essential oil of Cyperus rotundus. Phytochemistry
58(5): 799-810.

Tsao, R. 2010. Chemistry and biochemistry of dietary polyphenols. Nutrients 2(12): 1231-1246.

von Gadow, A., Joubert, E., Hansmann, C.F. 1997. Comparison of the antioxidant activity of aspalathin with that of other plant phenols of rooibos tea (Aspalathus linearis), $\alpha$-tocopherol, BHT, and BHA. Journal of Agricultural and Food Chemistry 45(3): 632-638.

Yen, G.C., Duh, P.D. 1993. Antioxidative properties of methanolic extracts from peanut hulls. Journal of the American Oil Chemists' Society 70(4): 383-386. 